\title{
Microalgae Grown in Cheese Whey and $\beta$-galactosidase Production
}

\section{Crescimento de Microalga em Soro de Queijo e Produção de ß-galactosidase}

\author{
Alessandra Bosso ${ }^{\text {a }}$ Naiale Fernanda da Silva Veloso ; Camila Fernanda Alba ; Josemeyre Bonifácio da Silva*aa; \\ Luiz Rodrigo Ito Morioka ${ }^{a}$; Hélio Hiroshi Suguimoto ${ }^{a}$
}

aUnopar, Programa de Pós-Graduação Stricto Sensu em Ciência e Tecnologia de Leite e Derivados. PR, Brasil. *E-mail: josibonifacio0576@gmail.com

\begin{abstract}
Cheese whey is the main by-product of dairy industry and due to high biological and chemical oxygen demands (BOD and COD) can cause several environmental problems. Recent studies have pointed the biotechnological potential uses of cheese whey such as fermentation medium to the $\beta$-galactosidase production. The enzyme is very important to breakdown the lactose into galactose and glucose, monosaccharide sugars more digestible than lactose. Microalgae can produce $\beta$-galactosidase through fermentative processes. The purpose of the current mini-review is to succinctly describe recent progress about the use of microalgae to $\beta$-galactosidase production. Overall, the paper summarizes the current state of knowledge about microalgae, beta-galactosidase and cheese whey as carbon source to growing of microalgae and within circular economy concept. However, there is still a need for further studies regarding the best microalgae cultivation conditions with the objective of producing the enzyme in question.
\end{abstract}

Keywords: Dairy Industry. Biotechnology. Circular Economy. Added Value.

\section{Resumo}

O soro de queijo é o principal subproduto da indústria de laticínios e a alta demanda biológica e química de oxigênio (DBO e DQO) pode causar vários problemas ambientais. Estudos recentes apontam os potenciais usos biotecnológicos do soro de queijo, como o meio de fermentação, para a produção de $\beta$-galactosidase. A enzima é muito importante para hidrólise da lactose em galactose e glicose, monossacarídeos mais digeriveis pelo organismo humano. As microalgas podem produzir a $\beta$-galactosidase através de processos fermentativos. O objetivo da presente revisão é descrever sucintamente o progresso recente sobre o uso de microalgas na produção de $\beta$-galactosidase. No geral, o artigo resume o estado atual do conhecimento sobre microalgas, beta-galactosidase e soro de queijo como fonte de carbono para o crescimento de microalgas e dentro do conceito de economia circular. No entanto, ainda são necessários estudos adicionais sobre as melhores condições de cultivo de microalgas com o objetivo de produzir a enzima em questão.

Palavras-chave: Indústria de lacticínio. Biotecnologia. Economia Circular. Valor Agregado.

\section{Introduction}

Cheese whey is the main by-product generated by cheese industry and its the current total worldwide production is estimated in about 180 to 190 million tons/year every (DIMOU et al., 2019). The waste when is incorrectly discarded into the environment can affect crop yields whenever applied on the soil and also imposes danger to the aquatic life when released into waters as it reduces dissolved oxygen levels (YADAV et al., 2015; PANESAR; KENNEDY, 2012). To avoid the environmental problem, recent studies have pointed the biotechnological potential uses of cheese whey such as whey bioconversion into useful products such as ethanol and bioplastics (RYAN; WALSH, 2016), products with value added such as functional and bioceutical ingredients offering thus, a sustainable waste management option (DIMOU et al., 2019). The use of cheese whey as added value product is relevant for the implementation of sustainable development goals and within economy circular concept (STANCHEV et al., 2020).

Lactose, the major constituent of cheese whey, is responsible for its high biological and chemical oxygen demands (BOD and COD) and which cause the several environmental problems (RYAN; WALSH, 2016). The disaccharide sugar found in milk and dairy products and its presence is related to intolerance lactose, a disease which causes symptoms such as bloating, nausea, abdominal cramping, and diarrhea (OAK; JHA, 2018). The intolerance lactose is characterized by inability of lactose digestion due to low levels of $\beta$-galactosidase enzyme activity. The $\beta$-galactosidase or lactase breaks the lactose into galactose and glucose, monosaccharidesugars more digestible than lactose (ANISHA, 2017). The enzyme can be produced by microorganism (yeast, fungi, bacteria and actinomycetes), plants and animal tissues. Through fermentative processes, the food industry has used the microorganisms to produce the enzyme and consequently break the lactose present in dairy products, an alternative to intolerance lactose people.

Recent studies about biotechnological food have also pointed out that microalgae are promising for the production of $\beta$-galactosidase enzyme (BENTAHAR et al., 2019a; ZANETTE et al., 2019; BENTAHAR et al., 2019b). The 
researchers demonstrate the ability of microalgae to hydrolyze lactose under grown different conditions and to outstanding great potential in the biomass and $\beta$-galactosidase production. As an example, there are the studies of the authors, Salati et al. (2017) which concluded that the cheese whey, used as carbon source, was better to biomass production compared with white wine lees and glycerol.

The purpose of present mini-review is to succinctly describe recent progress about the use of microalgae to $\beta$-galactosidase production. Overall, the paper summarizes the current state of knowledge about microalgae, beta-galactosidase and cheese whey as carbon source to growing of microalgae and within of circular economy concept. However, there is still a need for further studies regarding the best microalgae cultivation conditions with the objective of producing the enzyme in question.

\section{Development}

This review aimed at pointing the relationship among microalgae, beta-galactosidase and cheese whey. To study the science direct and CAPES portal and the keywords describe above were used as data base.

\subsection{Cheese whey}

Traditionally, cheese whey can be used as animal feed (pigs, sheep and cattle), as land spread or fertilizer (RYAN; WALSH, 2016). Cheese whey, greenish-yellow liquid, is obtained of milk manufacturing after the curd separation (namely milk casein) from the solid part resulting from the milk coagulation by acid or proteolytic enzymes (CARVALHO; PRAZERES; RIVAS, 2013; PANESAR; KENNEDY, 2012). Therefore, depending on the processing technique, cheese whey can be sweet or acid. Sweet whey has a pH of 5.6 and is made by the addition to milk of rennet, a mixture of enzymes containing the protease chymosin. The acid whey which has a $\mathrm{pH}$ of approximately 4.5 , is created by either the activity of lactobacilli or the addition of organic (lactic acid) or mineral acids (hydrochloric or sulphuric acid) (PANESAR et al., 2007). In cheese whey, $93 \%$ of the total volume is water and the principal nutrients are lactose (70-72 \% of the total solids), whey proteins $(8-10 \%$ of the total solids), and mineral salts (12-15\% of the total solids) (VENETSANEAS et al., 2009) and other minor components.

Incorrect discard of cheese whey has become a problem serious due to very high Biochemical Oxygen Demand (BOD) and high Chemical Oxygen Demand (COD) besides the volume generated. The major constituent which causes the high values for BOD and COD is lactose (PATEL; MURTHY, 2011). Its dump into municipal sewers interrupts the biological process of wastewater treatment plants; in the land it generates pollution surrounding the environment by affecting the soil physicochemical characteristics and decreasing crop yields; when disposed into water bodies, it reduces the dissolved oxygen, hampers biodegradability, and poses a major risk to aquatic life, and to environment and human health (GHALY et al., 2007; YADAV et al., 2015; SLAVOV, 2017). Thus, the conversion of cheese whey into value-added products can be an excellent alternative for its correct utilization, avoiding its disposal in the environment. Biotechnological process to the use of cheese whey has been described by various authors. Ryan and Walsh (2016) describe various biotechnological used of whey: to make human food products such as whey cheese and beverages, whey powders and whey permeate, whey protein, bioconversion of whey into useful products such as ethanol and bio-plastics. Valta et al. (2017) through a literature review revealed that cheese whey and whey components can be used in a wide range of applications, mainly in the food and nutraceutical industry, as they contain several beneficial compounds that can be exploited. Lappa et al. (2019) showed the recent advances regarding the conversion of whey into high value-added products, focusing on food applications, novel integrated biorefining concepts, and within the context of circular economy, high value-added products reintroduced in the food supply chain, thereby enhancing sustainability and creating "zero waste" processes. In a recent search on this subject in the literature, it is possible to observe the positive impact of the reuse of cheese whey avoiding waste in the environment (STANCHEV et al., 2020).

\section{$2.2 \beta$-galactosidase enzyme}

The lactose, 4-O- $\beta$-D-galactopyranosyl-D-glucose, the major constituent of cheese whey (44-52 g/L, acid or sweet whey), is a disaccharide sugar found in milk and dairy products. In the food industry, the lactose is used to promote crust browning through the Maillard reaction and is also added to cow's milk in the preparation of infant formula. However, due to low solubility, low sweetness, and mainly lactose intolerance problems, it has some limited uses. Therefore, the food industry has employed the $\beta$-galactosidase enzyme, in enzymatic catalysis or microbial fermentations for the processing of lactose-hydrolyzed products (ANISHA, 2017).

$\beta$-D-Galactosidase or lactase (EC 3.2.1.23; $\beta$-Dgalactoside galactohydrolase) is an enzyme used to hydrolize the lactose into galactose and glucose, monosaccharide sugars by breakdown of b-1,4-D-galactosidic linkages. In this way, the lactase demonstrates the ability to remove lactose from milk products for lactose intolerant people and production of galactosylated products. In addition, its application in food industry improves the sweetness, solubility, flavor and digestibility of dairy products (PANESAR et al., 2010).

Lactose intolerance is a disease characterized by the inability to digest and absorb lactose due to the low activity or low production of the $\beta$-galactosidase enzyme (DI COSTANZO; CANANI, 2018). The non-metabolized and not absorbed lactose in the small intestine reaches the colon, where it is fermented releasing $\mathrm{CO}_{2}$ and $\mathrm{H}_{2}$ gas and short is 
chain fatty acids producing acetate, butyrate and propionate. The symptoms are flatulence, abdominal discomfort, diarrhea, nausea, vomiting and constipation. Lactose intolerance affects many people in the worldwide and the treatment is based on the partial exclusion of dairy products from diet, breastfeeding, or use of lactose-free infant formulas (WOOTEN, 2010).

$\beta$-galactosidase enzyme can be produced by many organisms including microorganisms (yeast, fungi, bacteria and actinomycetes), plants and animal tissues. Its properties may vary as to the molecular weight, amino acid chain length, active site position, $\mathrm{pH}$ and thermal optimum and stability, specificity, and structure (MLICHOVA; ROSENBERG, 2006). $\beta$-galactosidases from bacterial sources show ease fermentation, high enzyme activity and good stability (HUSAIN, 2010). The Lactic Acid Bacteria (LAB), comprises a varied group of lactococci, streptococci, and lactobacilli, and owing to their GRAS (generally regarded as safe) status, are widely used in food. Bifidobacterium sp. and Lactobacillus $s p$. are the bacteria that are used as probiotics in food and food systems because of their potential health benefits (TARI et al., 2009). Fungal enzymes are generally extracellular and thermostable, but susceptible to end-product inhibition, mainly by galactose (ANISHA, 2017). Lactase from yeast is intracellular enzyme that shows a high lactose-hydrolyzing ability and is hence used commercially for the production of reduced-lactose milk for use by the lactose intolerant population (RECH; AYUB, 2007). Kluyveromyces marxianus is capable of growing on various substrates including lactose as the sole carbon and energy source (AL-JAZAIRI et al., 2015). An important recent source of discovery of $\beta$-galactosidase production comprises the microalgae. The microalgae as enzyme producers could have several advantages as their low nutritional requirements $\left(\mathrm{CO}_{2}\right.$, cheap nitrogen sources, light from either natural or artificial sources, water, and salts) and synthesis of other valuable by-products might improve the process profitability (BRASIL et al., 2017).

\subsection{Microalgae}

Microalgae comprise a group of versatile microorganisms that have diverse biotechnological uses, including production of biofuels (BEHERA et al., 2015), biofertilizers (DINESHKUMAR et al., 2017), and bioplastics (RAHMAN; MILLER, 2017). However, according to Brasil et al. (2017) some reviews describe the utilization of microalgae for value products and biotechnological applications but, a few address the potential of microalgae to be used as producers of industrially enzymes.

Microalgae are found in aquatic bodies, such as freshwater, marine and brackish water system and can grow in heterotrophic, mixotrophic and autotrophic conditions (PEREZ-GARCIA et al., 2011; BRASIL et al., 2017). In heterotrophic conditions, the microalgae are grown in the dark and obtain energy from organic carbon present in the medium. In mixotrophic conditions, they obtain energy from light and different inorganic and organic carbonic sources. Autotrophic is a culture method in the light and use the organic carbon as energy source (GHOSH et al., 2016; PEREZ-GARCIA et al., 2011). In all the tropic culture methods, factors such as light, nutrients, aeration, temperature and $\mathrm{pH}$ are important to their cultivation. Mirzaie et al. (2016) investigated the mixotrophic, heterotrophic and autotrophic growth of Chlorella vulgaris under agricultural waste medium and concluded that in mixotrophic growth the biomass and lipid content was higher than heterotrophic and autotrophic growth. However, Liang et al. (2009) showed that in autotrophic conditions, the microalgae have more lipids content and biomass and glucose as carbon source showed better effect on biomass productivity. Oh et al. (2009) working with Porphyridium cruentum in different culture conditions concluded that the best growth was in heterotrophic and glucose had a better carbon source. Regardless of the microalgae cultivation conditions, one of its main requirements is the supply of carbon as a source of energy. Gim et al. (2016) studied the effects of carbon source and light intensity on the growth and total lipid production of three microalgae under different culture conditions. The authors concluded that the glucose improved the growth of all the three strains. Salati et al. (2016) in mixotrophic cultivation of Clorella for local protein production using agro-foods byproducts, such as cheese whey, concluded that the waste represents an interesting approach to boost algae production with particular interest to protein production.

To date, there are few reports in the literature about the use of dairy industry by-product as a carbon source for microalgae growth and beta-galactosidase production. Bentahar et al. (2019) investigated the use of acid whey permeate for the production of microalgae biomass and $\beta$-galactosidase enzyme as a value-added product. Results show that biomass and enzyme production increase following the amount of whey permeate used in the medium formulation. In another study, Bentahar et al. (2019) investigated the production of $\beta$-galactosidase from T. obliquus under different trophic conditions and known media composition, in order to assess its influence on its productivity and selectivity. Results showed that the photoautotrophic cultures provide a higher selectivity, while mixotrophic conditions provide higher productivities due to faster growth and higher biomass yields. Further studies on mixotrophic cultures using lactose revealed no significant differences on $\beta$-galactosidase production when varying the concentrations of organic carbon and nitrogen nutrients. The age of culture has a strong influence on the enzyme production, suggesting a dependence on the growth phase. Maximal enzyme productivities obtained in mixotrophic conditions on lactose reach about $12.35 \mathrm{U} \mathrm{L}^{-1}$ day $^{-1}$ after 7 days, which is a realistic duration for producing the enzyme at larger scales in bioreactors. Zanette et al. (2019) studied the microalgae mixotrophic cultivation for beta-galactosidase production using lactose as a carbon source. The researchers concluded that even though enzyme activity values were low, 
mixotrophic microalgae cultivation demonstrated excellent biotechnological potential for contributing to biomass and biomolecule production and for the enhanced utilization of dairy products' industry coproducts.

\subsection{Others application}

Microalgae represent a potential sustainable alternative as producer Galactooligosaccharides (GOS) and for the enhancement and protection of agricultural crops. Suwal et al. (2019) verified that whey permeate (WP), a major byproduct of the dairy industry, obtained from the cheese whey ultrafiltration and rich in lactose, represents an interesting medium for producing GOS as high value-added ingredients. Using the microalgae Tetradesmus obliquus as the enzyme source could be an interesting alternative due to its lower nutritional requirements for growth and its applicability in industry. The authors investigated the growth of T. obliquus and its potential to produce GOS in WP compared to modified Bold's Basal medium (BBM). The growth rate of $T$. obliquus was significantly higher in WP, reaching a biomass concentration 4.5 times higher than when growing in BBM. Besides that, they detected, for the first time, the production of a trisaccharide GOS in WP whose concentration increased with time, reaching $4.4 \mathrm{~g} / \mathrm{L}$ and conversion yield of $8.4 \%$ (w/w of initial lactose) after 21 days.

The cellular extracts and growth medium of several microalgae species have been shown to contain phytohormones (gibberellins, auxin, and cytokinin), which are known to play crucial roles in plant development (TARAKHOVSKAYA et al., 2007). Studies utilizing both the application of growth medium from different origins and cellular extracts from various algal species have shown a clear effect on plant development with the application of the algal extracts and the algal growth media (TARAKHOVSKAYA et al., 2007; STIRK et al., 2013; GRZESIK; ROMANOWSKA-DUDA, 2014).

\section{Conclusion}

In this brief review, it is evident the need for more studies on the best microalgae cultivation condition using agroindustrial residues, such as cheese whey, as a carbon source, aiming at the production of the $\beta$-galactosidase enzyme and others application.

\section{References}

ANISHA, G.S. $\beta$-galactosidases. Current Developments in Biotechnology and Bioengineering: Production, Isolation and Purification of Industrial Products 17: 395- 421, 2017.

AL-JAZAIRI, M. et al. Optimization of $\beta$-galactosidase production by response surface methodology using locally isolated Kluyveromyces marxianus. Int. Food Res. J., v.22, n.4, p.1361-1367, 2015.

BENTAHAR, J.et al. Acid whey permeate: An alternative growth medium for microalgae Tetradesmus obliquus and production of $\beta$-galactosidase. Algal Research, v.41, p.1015-1059, 2019a. doi: 10.1016/j.algal.2019.101559

BENTAHAR, J. et al. Investigation of $\beta$-galactosidase by microalgae Tetrademus obliquus in determined growth conditions. J. Appl. Phycol., v.31, p.301-308, 2019b. doi: 10.1007/s10811018-1550-y

BEHERA, S. et al. Scope of algae as third generation biofuels Frontiers in bioengineering and biotechnology. Biotechnology, v.90, n.2, p.1-13, 2015.

BRASIL, B.D.S.A.F. et al. Microalgae and cyanobacteria as enzyme biofactories. Algal Res., v.25, p.76-89, 2017.

CARVALHO, M.F.; PRAZERES, A.; RIVAS, J. Cheese whey wastewater: Characterization and treatment. Science total environment. 445-446C: 385-396, 2013. doi:10.1016/j. scitotenv.2012.12.038

DI COSTANZO, M.; CANANI, B.R. Lactose intolerance: common misunderstandings. Ann. Nutr. Metab., v.73, p.30-37, 2018. doi:10.1159/000493669

DIMOU, C. et al. Valorization of cheese whey to "bio"-value added food products with industrial interest and their potential beneficial health effects. Int. J. Horticulture, Agriculture Food Sci., v.3, n.2, p.64-74, 2019. doi:10.22161/ijhaf.3.2.5

DINESHKUMAR, R. et al. Microalgae as bio-fertilizers for rice growth and seed yield productivity. Waste Biomass Valor, 2017. doi:10.1007/s12649-017-9873-5.

GHALY, A.E. et al. Potential environmental and health impacts of high land application of cheese whey. AJABS, v.2, p.106-117, 2007.

GHOSH, A. et al. Progress toward isolation of strains and genetically engineered strains of microalgae for production of biofuel and other value added chemicals: a review. Energy Convers Manag., v.113, p.104-118, 2016.

GIM, G.H. et al. Effects of carbon source and light intensity on the growth and total lipid production of three microalgae under different culture conditions. J. Ind. Microbiol. Biotechnol., v.43, 2016. doi:10.1007/s10295-016-1741-y

GRZESIK, M.; ROMANOWSKA-DUDA, Z. Improvements in germination, growth, and metabolic activity of corn seedlings by grain conditioning and root application with cyanobacteria and microalgae. Polish J. Environ. Studies, v.23, p.1147-1153, 2014.

HUSAIN, Q. Beta galactosidases and their potential applications: a review. Crit. Rev. Biotechnol., v.30, p.41-62, 2010.

LAPPA, I.K. et al. Cheese whey processing: integrated biorefinery concepts and emerging food applications. Foods, v.8, p.347, 2019. doi: $10.3390 /$ foods 8080347

LIANG, Y.; SARKANY, N.; CUI, Y. Biomass and lipid productivities of Chlorella vulgaris under autotrophic, heterotrophic and mixotrophic growth conditions. Biotechnol. Lett., v.1, p.1043-1049, 2009. doi:10.1007/s10529-009-9975-7.

MLICHOVÁ, Z.; ROSENBERG, M. Current trends of $\beta$-galactosidase application in food technology. J. Food Nutr. Res., v.45, p.47-54, 2006.

MIRZAIE, M.A.M. et al. Kinetic modeling of mixotrophic growth of Chlorella vulgaris as a new feedstock for biolubricant. J. Appl. Phycol., v. 28, n.5, p.2707-2717, 2016.

OAK, S.J.; JHA, R. The effects of probiotics in lactose intolerance: a systematic review. Crit. Rev. Food Scie. Nutr., 2018. doi:10.10 80/10408398.2018.1425977

$\mathrm{OH}$, S. et al. Lipid production in Porphyridium cruentum grown under different culture conditions. J. Bioscie. Bioengin., v.108, 
p.429-434, 2009. doi:10.1016/j.jbiosc.2009.05.020

PANESAR, P.S. et al. Permeabilization of yeast cells with organic solvents for $\beta$-galactosidase activity. Res. J. Microbiol., v.2, p.3441, 2007.

PANESAR, P.S.; KUMARI, S.; PANESAR, R. Potential applications of immobilized beta-galactosidase in food processing industries. Enzyme Res., 2010. doi:10.4061/2010/473137

PANESAR, P.S.; KENNEDY, J.F. Biotechnological approaches for the value addition of whey. Crit. Rev. Biotechnol., v.32, n.4, p.327-348, 2012.

PATEL, S.; MURTHY, Z.V.P. Waste valorization: Recovery of lactose from partially deproteinated whey by using acetone as anti-solvent. Dairy Sci Tech., v. 91, p.53-63, 2011.

PEREZ-GARCIA, O. et al. Heterotrophic cultures of microalgae: metabolism and potential products. Water Res., v.45, p.11-36, 2011. doi:10.1016/j.watres.2010.08.037

RAHMAN, A.; MILLER, C.D. Chapter 6 - microalgae as a source of bioplastics. Algal Green Chem., 2017. doi:10.1016/ B978-0-444-63784-0.00006-0

RECH, R.; AYUB, M.A.Z. Simplified feeding strategies for fed-batch cultivation of Kluyveromyces marxianus in cheese whey. Process Biochem., v.42, p.873-877, 2007. doi:10.14710/ ijred.2.3.127-131.

RYAN, M.P.; WALSH, G. The biotechnological potential of whey. Rev. Environ. Sci. Biotechnol., v.15, p.479-498, 2016. doi: 10.1007/s11157-016-9402-1.0.

SALATI, S. et al. Mixotrophic cultivation of Chlorella for local protein production using agro-food by-products. Bioresour. Technol., v.230, p.82-89, 2017.

SLAVOV, A. Dairy wastewaters - general characteristics and treatment possibilities: a review. Food Technol. Biotechnol., v.55, 2017 doi:10.17113/ftb.55.01.17.4520.

STIRK, W.A. et al. Auxin and cytokinin relationships in 24 microalgal strains. J. Phycol., v.49, p.459-467, 2013.

SUWAL, S. et al. Evidence of the production of galactooligosaccharide from whey permeate by the microalgae Tetradesmus obliquus. Algal Res., v.39, p.101-470, 2019.

STANCHEV, P. et al. Multilevel environmental assessment of the anaerobic treatment of dairy processing effluents in the context of circular economy. J. Cleaner Production, v.261, p.121-139, 2020. doi:10.1016/j.jclep ro.2020.121139.

TARAKHOVSKAYA, E.R.; MASLOV, Y.I.; SHISHOVA, M.F. Phytohormones in algae. Russian J. Plant Physiol., v.54, p.163$170,2007$.

TARI, C.; USTOK, F.I.; HARSA, S. Optimization of the associative growth of novel yoghurt cultures in the production of biomass, B-galactosidase and lactic acid using response surface methodology. Int. Dairy J., v.19, p.236-243, 2009.

VALTA, K. et al. Current treatment technologies of cheese whey and wastewater by greek cheese manufacturing units and potential valorisation opportunities. Waste Biomass Valor, v.8, p.1649-1663, 2017. doi:10.1007/s12649-017-9862-8

VENETSANEAS, N. et al. Using cheese whey for hydrogen and methane generation in a two-stage continuous process with alternative $\mathrm{pH}$ controlling approaches. Bioresource Technol., v.100, p.3713-3717, 2009. doi:10.1016/j.biortech.2009.01.02

WOOTEN, W.J. Lactose intolerance and ethnic prevalence. In: NATIONAL INSTITUTES OF HEALTH. Lactose intolerance and health. Kensington: National Institutes of Health, 2010. p.4952.

YADAV, J. et al. Cheese whey: A potential resource to transform into bioprotein, functional/nutritional proteins and bioactive peptides. Biotechnol. Adv., v.3, p.756-774, 2015.

ZANETTE, C.M. et al. Microalgae mixotrophic cultivation for $\beta$-galactosidase production. J. Appl. Phycol., 2019. doi:10.1007/ s10811-018-1720-y 